\title{
DATOS PARA UNA CRONOLOGÍA DE LA ARQUITECTURA MILITAR DE SHARQ AL-ANDALUS: LAS PUERTAS DE LA ALCAZABA DE DENIA Y SUS PARALELOS, Y LA FORTA- LEZA DE CHERA (VALENCIA)
}

\author{
Basilio PAVÓN MALDONADO \\ C.S.I.C. Madrid
}

\section{1- ALCAZABA DE DENIA Y SUS PUERTAS}

Denia -Dãniya- ha sido objeto últimamente de varios estudios novedosos de gran interés ${ }^{1}$. María Jesús Rubiera da en su libro de $L a$ taifa de Denia dos interesantes piezas artísticas que encabezan arqueológicamente la historia de la ciudad: una basa de tipo califal y lápida funeraria con el año 1057, esta última conservada en Benidorm. La basa es de mármol con exquisita decoración labrada. Tiene plinto, dos toros y escocia entremedia respondiendo al tipo de basa ática de la Antiguiedad, replicada en buen número de basas del Califato de Córdoba, principalmente en Madinat al-Zahrā'. En esta ciudad palatina se registran las tres modalidades decorativas de la basa de Denia, que es casi gemela de una basa exhumada en aquélla en los últimos años ${ }^{2}$. En mi libro El arte hispanomusulmán en su decoración floral aparece la

${ }^{1}$ Rubiera Mata, M. J., La taifa de Denia, Alicante, 1985, 1988; y Azuar, R., "La portada interior de la Torre del Mig de la alcazaba de Denia", Sharq alÁndalus. Estudios Árabes, Alicante, I, 1984, pp. 123-130; y Denia islámica. Arqueología y poblamiento, Alicante, 1989.

${ }^{2}$ Pavón Maldonado, B., El arte hispanomusulmán en su decoración floral, Madrid, 1988: número 120 de Tabla V-15 (foto). 
decoración del plinto de la basa alicantina ${ }^{3}$, la de la escocia ${ }^{4}$ y las cintas con cordón de dos ramales de los toros o boceles ${ }^{5}$. Hace años fotografié una basa califal del Alcázar de Sevilla cuyo plinto se anima con la misma decoración del plinto de la basa de Denia. A los talleres califales de Madīnat al-Zahrā' habrá que atribuir la basa alicantina, dentro de la segunda mitad del siglo $X$.

Importante es la lápida mencionada, de la segunda mitad del siglo XI, época en que sin duda estarfa ya levantada la alcazaba, a la que se añadiría, entre los últimos años de esa centuria y los primeros de la siguiente, la puerta de la Torre del Mig que daba entrada al recinto anexo de NE, si no a la misma fortaleza. En el lado opuesto está la llamada Puerta del Baluarte, entrada directamente relacionada con la alcazaba, reformada probablemente en época almohade e incluso la cristiana. Rubiera y Azuar ${ }^{6}$ dieron las primeras ilustraciones de ambas puertas, que he tenido oportunidad de ver y dibujar últimamente. A mi juicio, la puerta árabe oculta en la torre cristiana del Mig se erigirfa, como he dicho, en la transición del siglo XI al XII, siendo por tanto construcción almorávide, con paralelos que iremos viendo a lo largo de este trabajo.

La puerta de la Torre del Mig tiene en planta un codo sencillo que, como es sabido, aparece por primera vez en las puertas granadinas de los Pesos y de Monaita (s. XI), si se exceptúan las puertas -que yo he llamado de codo topográfico- del castillo califal de Gormaz ${ }^{7}$ y de Alcántara de Toledo ${ }^{8}$. La planta es cuadrada, de 4,19 metros de lado, $y$ las entradas exterior e interior enseñan el juego de las cuatro mochetas, es decir, un arco a continuacion de otro. La fachada exterior está muy deteriorada, pero sustancialmente tiene el mismo programa de

${ }^{3}$ Ibidem, Tabla V, pp. 41-42-43, y Tabla V-15, número 115 (foto).

${ }^{4}$ Ibidem, Tabla XVII, pp. 103-104-105 y Tabla XXV-83, número 512 (foto).

${ }^{5}$ Ibidem, generalizada en boceles y cenefas estrechas.

${ }^{6}$ Obras citadas.

${ }^{7}$ Zozaya, J., Islamic Fortifications in Spain: some aspects, B. A. R., 1984, pp. 636-673.

${ }^{8}$ Pavón Maldonado, B., "Las puertas de ingreso directo en la arquitectura hispanomusulmana", Al-Qantara, Madrid, VIII, 1987, p. 360, fig. 8. 
la puerta interior, ligeramente modificada. Tiene ésta arco de medio punto algo peraltado, dibujado dentro de alfiz rehundido, sin impostas a la vista y con dovelas convergentes al punto medio de la línea de impostas, pero con la novedad de dibujarse las extremas fuera de la caja del alfiz. Sobre el arco se ve otro ciego y de medio punto con dovelas de piedra entre las que alternan piezas enteras y piezas partidas; en realidad, este arco es el reflejo de la bóveda del interior, que figura en la fachada cual si fuera arco de descarga, según aparece ya en la fachada exterior de la Puerta de los Pesos, de Granada, aquí de ladrillo. Esta superposición de arco, ciego el superior, de origen romano y bizantino -la puerta de San Pedro de las murallas romanas de Lugo tiene este tipo de puerta-, se ve ya en la puerta califal de la medina de Ágreda (Soria), en Bāb al-Qablī (s. XI) del ribat de Tit, en Marrruecos, y en una de las puertas del primitivo Alcázar de Sevilla.

El arco de la Puerta del Mig tiene 1,82 metros de luz, 1,24 de altura y jambas de 1,47 de altura. La profundidad de los compartimentos entre las mochetas es de 1,05 metros. Como la Puerta de Monaita de Granada, es probable que las gorroneras fueran de madera, tal como se ve hoy. Lo que más llama la atención de los arcos de la puerta alicantina es la rosca de medio punto, si bien pudiera tratarse de un arco modificado en los arranques, siendo primitivamente de herradura; pero esto parece muy incierto. La arquitectura árabe conoce arcos de medio punto, con o sin jarjas, como lo prueban el arco interior de la puerta del castillo califal de Tarifa, la Puerta del Mayordomo en Toledo, los arcos de las puertas granadinas, de época zirí, y las de Hernán Román y de Elvira, según grabados de Heylan del siglo XVII, la puerta de Alpuente (Valencia) ${ }^{9}$, arcos interiores de las puertas del Socorro y de Sevilla, de Niebla, arco del Puente de la Torre Vieja -albarrana- de la alcazaba de Badajoz, los arcos interiores de las puertas de la Coracha y del Capiel de esa misma fortaleza y la puerta desaparecida de Santa Margarita, antigua Bāb al-Kuhl, en Palma de Mallorca. Una puerta árabe de medio punto se ve aún claramente en el castillo de Alcaudete (Jaén), y en el de Castro del Río -el hisn Qatrum de Ibn Hayyān- (Córdoba), hay otra

${ }^{9}$ Ribera, A., y Gómez, R., "El Castell d'Alpont (València). Noticia sobre restos constructivos de época califal", Actas I Congreso de Arqueología Medieval Española (1985), III, Andalusí. 
puerta islámica de piedra algo modificada, que enseña arco de medio punto y otros caracteres de la Puerta del Mig, que analizamos a continuación. Por último, un raro ejemplar se da en la fortaleza o albacar de Planes, que tendré oportunidad de describir más adelante.

Lo del alfiz rehundido, con las dovelas extremas dibujadas fuera de caja, es otra novedosa modalidad de la Puerta del Mig, que se repite en las siguientes puertas islámicas, comprendidas entre el siglo XI y XII: puertas de la cerca de Niebla, puerta de la Pastora, de Medina Sidonia, las comentadas entradas de los castillos de Castro del Río y de Alcaudete, y la puerta de Belén, del Corral de los Ballesteros, de Córdoba $^{10}$. Otra característica que ayuda a fijar cronologías es el arco sobrepuesto que traduce al exterior la bóveda de la habitación interna, arco que enseña alternativamente dovelas enteras y dovelas partidas. Esta última modalidad técnica es vieja en la arquitectura hispanomusulmana, viéndose ya en el puente de Córdoba, arcos gemelos contiguos a la desaparecida Puerta de Sevilla de la cerca de Córdoba, puente de Guadalbacar (Córdoba), arco del puente de la Torre Vieja -torre albarrana- de la alcazaba de Badajoz ${ }^{11}$, arco superior de la puerta de Santa Margarita, en Mallorca, y arcos interiores de la Puerta de Sevilla en Niebla ${ }^{12}$. En el Norte de África reaparece en el arco superior de la fachada exterior de Bāb al-Had, de Rabat, de época almohade.

Como se ha visto, la puerta de la Torre del Mig es ejemplar que se codea con otras entradas islámicas, todas de piedra y de la misma época, formando interesante repertorio que se puede adscribir a la segunda mitad del siglo XI o principios del XII. Discutible en este sentido es la cronología de la puerta cordobesa de Belén, pues algunos sillares enseñan marcas de canteros inusuales en obras hispanomusulma-

${ }^{10}$ Pavón Maldonado, B., "Entre la historia y la arqueología. El enigma de la Córdoba califal desaparecida", Al-Qantara, IX, 1988, pp. 175-176; y Gracia Bois, R., "El Corral de los Ballesteros", Boletín de la Real Academia de Córdoba, 90, 1970, pp. 5-24.

11 Pavón Maldonado, B., "Notas de arte, arquitectura y arqueología hispanomusulmana", Al-Qantara, 1993.

12 Arcos de piedra de la habitación interior sobre los que carga la bóveda baida de ladrillo. 
nas. Es probable que esas marcas las añadieran los cristianos, pues se encuentran en piedras del interior. Como conclusión, la alcazaba de Denia es erigida o rehecha cuando se levantan las puertas mencionadas de Alcaudete, Planes, Puerta de La Pastora de Medina Sidonia, puertas de Niebla, la Torre Vieja de la alcazaba de Badajoz, puerta cordobesa de Belén y quizá las puertas de Elvira y de Hernán Román de Granada. No hay indicios de que la puerta de Denia tuviera escalera interior para acceder al segundo cuerpo o terraza. Sólo detecto escalera interior en la mencionada del ribat de Tit, en la cordobesa de Belén y una cristiana, en codo. Por lo visto era prácticamente inusual en Al-Ándalus, pues la escalera de la torre de Belén parece cristiana; sin embargo se dan casos en las puertas almorávides de Marrakech.

No es caprichoso equiparar cronológicamente la puerta de Denia a las granadinas, en las que, exceptuada la de Hernán Román, aparece el ingreso en codo y el arco con alfiz rehundido. Un síntoma claro de arcaísmo de aquélla es que la supuesta rosca de herradura no es aguda, como la de Monaita de Granada, mientras que la de los Pesos de esta ciudad enseña, al igual que el arco exterior de la Puerta de Sevilla en Carmona y el de Alcalá la Real, por vez primera en la arquitectura militar hispanomusulmana, herradura apuntada. Este tipo de rosca es la más generalizada en la mayoría de puertas comentadas del siglo XII y las de las dos centurias siguientes.

Respecto al codo del pasadizo de las puertas hispanomusulmanas, codo sencillo, y sus orígenes, Torres Balbás ${ }^{13}$ ya señaló la mayor antigüedad, dentro de la segunda mitad del siglo XI, de las puertas de los Pesos y de Monaita, seguidas inmediatamente -añadimos nosotrosde la puerta primitiva de la alcazaba de Málaga, puerta de la Villa de Faro $^{14}$, puerta de la Torre del Mig de Denia y las cuatro de la cerca de Niebla. Sobre todas ellas la malagueña, la de Faro y la de Denia aportan como novedad el juego de cuatro mochetas correspondientes a los arcos dobles del interior y del exterior, adelantándose en ello a otras

13 Torres Balbás, L., "Las puertas en recodo de la arquitectura hispanomusulmana", Al-Andalus, XXV, 1960, y Ciudades hispanomusulmanas, П.

${ }^{14}$ Pavón Maldonado, B., Ciudades y fortalezas lusomusulmanas. Crónica de viajes por el Sur de Portugal, Madrid, 1993, p. 73 (planta en codo publicada por Joao de Almeida). 
puertas almohades y nazaries. Añadiendo a las puertas en codo hispánicas erigidas en el llano y no por razones topográficas, como lo fueron las comentadas del castillo de Gormaz y la de Alcántara de Toledo, ambas del siglo X, procede revisar sus orígenes. En contra de la opinión de Creswell que vio las primeras puertas en codo en la ciudad de Bagdad de la época abbasí, desestimiando las puertas en codo sencillo de los fuertes bizantinos de Anastasiana, Belezma y sobre todo de Tignica (Túnez), añadidas, según ese autor, en época árabe, Torres Balbás opinaba que estas últimas son bizantinas ${ }^{15}$. Las plantas de estos fuertes africanos fueron publicadas por S. Gsell, Diehl, Saladin y, últimamente, por Denys Pringle.

Más tarde, Lézine ${ }^{16}$ dio con dos puertas árabes tunecinas de la segunda mitad del siglo $\mathrm{X}$ y principios del XI, localizadas en la alcazaba de Susa y en el ribat de Monastir. Últimamente he tenido la oportunidad de ver y dibujar esas puertas tunecinas, la bizantina de Tignica y las dos árabes. La del fuerte de Tignica concretamente tiene las mismas fábricas de sillares que el resto de la fortaleza bizantina del siglo VI y no cabe hablar por tanto de que ese ingreso fuera añadido por los árabes. $Y$ respecto a los árabes de Susa y Monastir, también de codo sencillo, quedan dentro de una torre sobresaliente en planta, destacando la buhedera rasgada de la fachada exterior, que en Al-Ándalus se ve por vez primera en las puertas del castillo de Gormaz, Bisagra vieja de Toledo, de Sevilla en Carmona y las nazaríes tardías del castillo de Jimena de la Frontera y de la Justicia de la Alhambra, y al parecer también existio, impuesta en el siglo XIII, en la puerta granadina de Elvira. De Ifrīqiya debieron llegar a España, concretamente a Granada, las puertas de codo sencillo, bajo el gobierno de los soberanos ziríes Zawi, Habbus y Badis, emparentados con los ziries del Norte de África. Conocida es la rebeldía de Zawi b. Ziri, que, con familiares y adeptos, obtuvo autorización para salir de Ifrīqiya e irse a Andalucía después del

15 "Las puertas en recodo", y Creswell, Early Muslim Architecture, II, Oxford, 1940, pp. 26-29; y Fortifications in Islam before A. D. 1250, apud Proceeding of the British Academy, XXXVIII, London, 1952, pp. 101-105; A Short account of Early Muslim Architecture, Baltimore, 1958, pp. 174-179.

16 Lézine, A., Deux villes de Ifriqiya, Paris, 1971; y Architecture de l'Ifriqiya. Recherches sur les monuments aghlabites, Paris, 1960. 
año 1002, muerto ya el dictador Al-Manșūr, noticias que explica con detalle el polígrafo granadino Ibn al-Jatịb, en su Kitäb a'mal al$a^{\prime} \operatorname{lam}^{17}$. La puerta de la Torre del Mig, de Denia, vendría a continuación, dentro ya de la dominación almorávide. El punto más polémico sobre la prioridad cronológica de las puertas árabes en codo tunecinas se centra en la entrada en codo del ribat de Monastir, que tiene ya arco de herradura aguda, alfiz rehundido y dintel encima adovelado, como la granadina de los Pesos. Aquélla, según Lézine, se relaciona con las reformas introducidas en el ribat en el siglo XI, y ello no está muy descaminado considerando que la decoración floral de los arcos decorativos de la parte superior es de tipo aglabí, por tanto un arcaismo local, pero de otra parte el alfiz de arcos tunecinos en general es una prestación hispánica que se instala en Ifrīqiya entre finales del siglo $\mathrm{X}$ y los comienzos del XI, como lo prueba la Gran Mezquita de Susa, seguida del arco de la entrada de la antigua midhá de la Gran Mezquita de Qayrawán y de los arcos de las galerías del patio de este oratorio, rehechas en época hafșí (s. XIII), como reconoció Creswell. En trabajo aparte tendré oportunidad de describir detenidamente todos estos aspectos relativos a los paralelismos, analogías e influencias entre la arquitectura hispanomusulmana y la de Ifrīqiya.

La otra puerta, la del Baluarte, de la alcazaba de Denia, también merece nuestra atención. Tiene fachada exterior de piedra en talud, arco de herradura apuntada sin alfiz y dovelas enteras y partidas. El arco mide de luz 1,50 y altura hasta el trasdós de 2,70; y las jambas, 1,63. $\mathrm{El}$ ingreso es directo, modificado en época cristiana, pero el arco más interior deja ver rosca de herradura de piedra. El tramo primero de la entrada de dos mochetas tiene las paredes costales inclinadas, con convergencia imaginaria hacia fuera, modalidad que se ve en las puertas almohades Ruwah y de Had de Rabat. Esta última puerta tiene en el arco más superior alternancias de dovelas enteras y partidas. Creo que la puerta del Baluarte debe situarse entre el siglo XII y XIII, si bien con reformas cristianas seguras. Hoy la puerta exterior del albacar de la alcazaba enseña arcos de herradura aguda con dovelas enteras y

${ }^{17}$ Historia medieval islámica del Norte de Affica y Sicilia, traducción, notas e índices por Rafaela Castrillo, Madrid, 1983, pp. 53-57. 
partidas, modalidad que quedó en la ciudad cristiana como un remedo de las puertas árabes del siglo XI.

\section{2 - LAS PUERTAS DEL CASTILLO DE ALCAUDETE (JAÉN),} PLANES (ALICANTE) E IBIZA.

A) Castillo de Alcaudete.

Este castillo, merecedor de breve estudio como paralelo de la fortaleza de Denia y otras similares, es citado en dos ocasiones en el siglo IX, por Ibn al-'Idārī (Bayăn II). Se le conoce como hișn alQabdaq, en los alrededores de Jaén y vecino del Castillo de Lucubín ${ }^{18}$. Alcaudete y su tierra caen sucesivamente en poder de los cristianos, con Fernando III, y de los árabes entre los años 1240 y 1244, y definitivamente es ganada por aquéllos, junto a Alcalá la Real y el Castillo de Locubín, en $1338^{19}$. Yāqūt la llama "ciudad de los términos agrícolas de Córdoba, fortaleza bien poblada y mercado fructffero", y Al-Idrīsī dice que es "fortaleza considerable, bien poblada, al pie de una montaña que da cara a Occidente, con mercado frecuentado"20. Según Ibn alJațib, en el año 1300 Muhammad I acampa en la medina y la cerca, refugiándose los habitantes en su fortaleza; con este motivo se establecieron en la villa y rábita los musulmanes, y se construyó un foso.

En Al-Ándalus había otros Alcaudetes. En Portugal Alcabadeche, según Jaime Oliver Asín, y el Caudete de las Fuentes, en Valencia. María Jesús Rubiera, en su libro Villena en las calzadas romana y árabe ${ }^{21}$, escribe: "el Alcaudete andaluz -de la provincia de Jaén- está documentado en árabe como al-Qabdāq, transcripción árabe de Cap daq, es decir, caput aquae ("cabeza de agua"). Todos los Caudetes de la

${ }^{18}$ Aguirre Sádaba, F., y Jiménez Mata, M. del C., Introducción al Jaên islámico (estudio geográfico-histónico), Jaẻn, 1974; y Vallvé, J., "La división territorial de la España musulmana. La cora de Jaén", Al-Andalus, XXXIV, 1969.

${ }^{19}$ Nieto Cumplido, J., Corpus medievale cordubense (1106-1255), Córdoba, 1979, pp. 120, 141, 153.

${ }^{20}$ Idrisi, Description de l'Afrique et de l'Espagne, trad., notas y glosario de R. Dozy y M. J. de Goeje, Leide, 1866, p. 252.

${ }^{21}$ Alicante, 1985. 
región valenciana están en zona castellana y funcionan como Alcaudete". En el Alcaudete andaluz, junto a la muralla o barrera del primitivo hábitat árabe figura una vieja calle llamada del Agua.

Mucho debi 6 padecer la fortaleza árabe de Alcaudete, ubicada en lo alto del monte y rodeada de barbacana -repisa muy ajustada-. Tiene varias torres rectangulares, dos de ellas muy próximas dando custodia a la entrada árabe. Dentro de la fortaleza se conserva un aljibe abovedado árabe, cerca de la impresionante atalaya situada hacia el centro de la plaza. Pero esta torre, al igual que casi todos los lienzos murarios, la erigieron los cristianos, sin duda en sustitución de otra árabe de menor envergadura. Tiene planta rectangular de 11,70 por 14,90 metros, y el grueso de los muros no excede los 2,90. Por dentro enseña dos o tres plantas. De la fortaleza parte una muralla -hoy llamada La Barrera-, que rodeaba el primitivo hábitat islámico. En realidad, era un albacar que incluiría una mezquita ocupada ahora por la iglesia de Santa María. Por los alrededores del monte creció la población cristiana, con su Haza, el Barrio Nuevo y las calles del Agua y del Barranco.

La puerta del castillo, la única parte auténticamente árabe que se conserva en la fortaleza, es de ingreso directo, con cuatro mochetas y sus correspondientes arcos, exterior e interior. La bóveda de medio cañon de ladrillo del interior se refleja en ambas fachadas en forma de arco de medio punto, según se vio en Denia. Las gorroneras son piedra cuadrada. La fachada exterior de sillares queda flanqueada por sendas torres de mampostería. Tiene arco de medio punto muy peraltado, de 1,77 metros de luz y 3,02 de alto, con dovelas de 0,51 de ancho. La altura de las jambas se sitúa en 1,50. El arco se dibuja dentro de alfiz rehundido por fuera del cual se dibujan las extremas, incluidas las cuñas de las jarjas, según se vio también en Denia y en otros paralelos ya comentados. Por encima del arco se ve aquel superior de ladrillo de la bóveda interior. Esta fachada se repite exactamente igual en el interior.

En estas tierras de Jaén, aparte de muros y torres de tapial, el arco de la puerta de Alcaudete es uno de los escasos restos islámicos de piedra conservados del siglo XI. Otro arco de piedra de semejante cronología es el que permanece oculto dentro de la torre cristiana del 
homenaje, del castillo de Alcalá la Real ${ }^{22}$. Tiene rosca de herradura ligeramente apuntada, al parecer dentro de alfiz rehundido; está enjarjado y conserva sus dos impostas anaceladas. El ingreso parece que sería en codo, aunque sólo ha llegado el tramo exterior de las cuatro mochetas, con sus correspondientes gorroneras con baquetón cilíndrico añadido a la nacela, según modelo cordobés. Esta puerta la feché hace años entre el siglo XI y el XII, relacionándola con las granadinas de Monaita y de los Pesos, considerando que ésta última tiene arco de herradura aguda, el primero conocido en Al-Ándalus en la arquitectura militar. De la vecina del Castillo de Locubín -hisn al-'uqbin-tan sólo se conserva alto zócalo de fábrica de sillares bien escuadrados, probablemente árabes.

B) Planes.

En la cumbre del pueblo destaca sobre el caserío de la población una cerca, fortaleza o albacar de recios muros $-1,30$ metros de espesorcon ocho torres de tapial hormigonado. Sería fortaleza refugio como otros de la tierra alicantina ${ }^{23}$. La altura de las tapias o tabiya es de 0,80 metros. Este recinto de forma poligonal y alargado con sus torres rectangulares de distintos tamaños encierra aproximadamente 1.130 metros cuadrados; sin explorar aún el interior, no se ven restos de aljibe ni otro tipo de edificio. Del lado opuesto al pueblo, se encuentra la entrada precedida de un antemural o barbacana de 0,80 metros de espesor, también de tapial. Desde el arco exterior de la entrada hasta llegar al recinto existe pasadizo en codo con arco interior de dovelas de piedra, al parecer cristiano. Pero el arco exterior de la puerta es árabe.

Nuevamente vemos en él rosca rebajada de medio punto con 1,70 de luz por 2,43 de altura. El despiezo de las dovelas de lajas de piedra muy estrechas alternando con las tres superiores más anchas, aunque de

22 Pavón Maldonado, B., "Arte, símbolo y emblemas en la España musulmana", Al-Qantara, VI, 1985, pp. 110-111, fig. 1.

${ }^{23}$ Ferrer Merset, P., Muralles $i$ castells del Comtat; y Segura i Martí, J. $\mathrm{M}^{\mathrm{a}}$, y Torró i Abad, J., Catàleg castellològic de l'àrea de Treball del Museu Arqueològic Municipal d'Alcoi, C.A.H.A. 
forma irregular, todo muy desalineado pero con impronta árabe segura, que recuerda en parte el arco de la puerta de la población de Alpuente (Valencia). Tiene en los arranques a modo de jarjas, y la convergencia de las dovelas se sitúa aproximadamente en el punto medio de la base del vano de la puerta. Las lajas horizontales pisan alternativamente las dovelas formando típico escalonamiento propio de arcos árabes de los siglos X y XI. Una de las dovelas, como la puerta descrita de Alcaudete, enseña rebaje o rediente para mejor acoplamiento del dovelaje con las piedras horizontales. Dentro de su rareza, el trazado es árabe, adscribible al XI o principios del XII, en la frontera de la dominación almorávide y la almohade.

Planes en siglo XIII pasa a los cristianos, siendo señor de la fortaleza y villa Gil Garcés de Azagra (1259) y en 1261 lo era Guillén de Rocafull ${ }^{24}$. Como lo prueba su relativo buen estado de conservación, la fortaleza de Planes debió jugar un papel importante militar en todo tiempo.

C) Ibiza.

Las excavaciones practicadas estos últimos años entre los baluartes de San Jorge y de Santiago dan a entender que la muralla árabe de tapial hormigonado con mechinales de esta parte occidental no se corresponde con la erigida por allí en época cristiana tardía, según planta de Costa inspirada en dibujos del Archivo General de Simancas del siglo XV-XVI. Esta muralla árabe ahora aparecida, que se presenta con bastantes adherencias cristianas, tiene una puerta o postigo con arco de medio punto algo rebajado y enjarjado; hasta las jarjas las quince dovelas son de piedra formando a modo de arco rebajado o escarzano no inusuales en postigos de murallas islámicas, como el del Agujero de Niebla y otros más. El dovelaje del arco tiene 0,38 de ancho, y el arco 1,27 de luz y 1,70 de altura.

${ }^{24}$ Muralles i casells del Comtat. 


\section{3- LA FORTALEZA DE CHERA (VALENCIA)}

Una de las fortalezas más originales por su planta, de Sharq alÁndalus, es el llamado "Castillejo" de Murcia, seguida de la de Chera, próxima a Sot de Chera. Ambas de planta rectangular con torres en los ángulos y otras en los muros de los costados. Las dos tienen antemural o barbacana. La primera bien conocida y estudiada por Gómez-Moreno y Torres Balbás, era residencia-fortaleza almorávide ${ }^{25}$. La de Chera, prácticamente inédita, es fortaleza campera hoy semioculta por la vegetación salvaje de la campiña, fortaleza o albacar de sofisticada planta, con escasos paralelos dentro y fuera de Al-Ándalus. No parece que por allí hubiera población, siendo un fuerte, quizá atalaya inicialmente, dependiente de Sot de Chera en donde destaca, impresionante torre talaya de tapial, rodeada de cerca o barbacana muy ceñida.

El castillo de Chera tiene planta rectangular con torres cuadradas huecas en los ángulos y otra en medio de los costados mayores, simétricas. Esta cerca de cuatro torres o bury, que más parece ribat que otra cosa -recuérdese el ribat de la isla de San Fernando, de Cádiz-, se ve rodeada por una ceñida barbacana, que en planta dibuja exactamente la interior. La entrada, prácticamente irreconocible hoy, estaría en el costado S. y describiría a partir de la barbacana un doble codo.

Aproximadamente en el centro existe una torre atalaya cuadrada de 7 por 7,10 metros de lado, con muros de 1,05 de grosor. La puerta de ingreso estaba en alto, a 2 metros aproximados del suelo, y tenía dos o tres habitaciones de pisos improvisados de madera. Hoy está totalmente hueca. Toda la construcción es de tapial hormigonado con mucho canto, de 0,80 metros la altura de las tapias. Al pie la torre se reconoce la caja de la que, sin duda, sería cisterna o aljibe de forma cuadrada.

No se prodiga este tipo de planta en Al-Ándalus; sólo se le aproxima el comentado "Castillejo" de Murcia, a 500 metros del castillo de Monteagudo, ambos de época almorávide. En la provincia alicantina se ven plantas cuadradas o rectangulares con torres en los ángulos, en Albaida -cristiana-, el monte Almiserá -torres redondas de facturas

25 Gómez-Moreno, M., Ars Hispaniae, III, p. 280; y Torres Balbás, L., "Monteagudo y el Castillejo de la Vega de Murcia", Al-Andalus, II, 1934, pp. 366-372. 
cristianas inicialmente- y el castillo de Fornas, en el límite con la provincia de Valencia -casa señorial fortalecida cristiana con torre atalaya árabe reutilizada-. Si se prescinde de la barbacana, su paralelo más exacto es el castillo de San Romualdo de la isla de San Fernando, de Cádiz, estudiado por Torres Balbás ${ }^{26}$. Aquí de seguro hubo un ribat, si bien no está suficientemente probada su atribución a los árabes. Torres Balbás estuvo indeciso acerca de si era fortaleza árabe o cristiana del siglo XIV erigida por mano de obra musulmana. La construcción es también de tapial hormigonado, pero con zócalos de recios sillares vistos, en algunos tramos de la cerca exterior. Se asemeja a Chera por las torres cuadradas de los ángulos, otras dos en los costados mayores y, como novedad, una tercera en uno de los frentes menores, posiblemente correspondiente a capilla cristiana añadida. Como quiera que fuere, este castillo gaditano y el de Chera tienen un parecido sorprendente, si se prescinde de la barbacana del último. Otro castillo o albacar propiamente dicho es el de Marmolejo (Jaén), dibujado por Jimena Jurado en el siglo $\mathrm{XVII}^{27}$. Tiene éste planta rectangular con torres redondas en los ángulos y torre atalaya aislada hacia el centro, como en Chera. Y en el castillo de Álora (Málaga) la planta cuadrada enseña también torres cuadradas en los ángulos y una centrada en dos de sus $\operatorname{costados}^{28}$. No voy a extenderme a fortalezas hispanomusulmanas con torres en los ángulos y otras en los costados, tipo campamento de origen romano-bizantino que se prodigan en el Norte de África y en la arquitectura omeya de Siria. Únicamente citar fortalezas bizantinas norteafricanas de Thamugadi, Qasr Belezma, Anastasiana, Tubunae -fuertes de ocho torres- o los de Castal y Diana Veteranorum -solo con torres en los ángulos- ${ }^{29}$; o los ribats árabes de Susa y Monastir

26 Torres Balbás, L., "El Castillo del lugar de la Puente, en la Isla de Cádiz", Al-Andalus, pp. 271-289.

${ }^{27}$ Eslava Galán, J., "El fuerte cuadrado en España", Revista de Arqueología, 55,1985 , p. 50 .

${ }^{28}$ Pavón Maldonado, B., Ciudades hispanomusulmanas, Madrid, 1992, pp. 195-196.

29 Pringle, D., The defense of Byzantine Africa from Justinian to the arab Conquest, I-II, 1981. 
(Túnez). Con estos últimos relacionó Torres Balbás el castillo ribat gaditano comentado, por las habitaciones interiores en torno al patio.

La fortaleza de Chera parece un híbrido de residencia señorial fortificada y albacar o cortijo del campesinado, que alli encontraba seguro refugio en los momentos de peligro. El binomio de cerca torreada y torre atalaya aislada en medio, era un clisé muy frecuente en la castellología hispanomusulmana, retomada o imitada por los cristianos. Torre y cerca o cortijo que servían de refugio de moros cuando eran acosados por los cristianos se citan en la provincia de Jaén ${ }^{30}$. Para la castellología levantina es útil conocer una de las torres atalayas almohades de los alrededores de Badajoz, llamada de los Rastros, aún en pie, de planta octogonal y con Barbacana muy ceñida, de planta cuadrada, cuya entrada en codo curiosamente carece de gorroneras, es decir no tenía portezuelas. Las grandes torres atalayas árabes, como lo confirman varias de la tierra de Córdoba, tenían barbacana o cortijo, incluidas las cristianas, réplicas de aquéllas. Ese clisé de cerca y atalaya tiene el recinto de Chelva (Valencia), viéndose también en Cazorla (Jaén), Alcaudete, Jódar, castillos toledanos de Almonacid y de Mora, y otros de la provincia de Guadalajara. Un ejemplo tardío (s. XV-XVI) de este tipo de fortaleza, que es citado en documentos moriscos, es el castillo de Rodalguilar (Almería), formado por especie de barbacana de planta rectangular con torres redondas en los ángulos y torre atalaya en el centro. En realidad, los castillos de tapial árabe del valle del Vinalopó eran sustancialmente grandes torres atalayas autosuficientes rodeadas por albacar abarbacanado. Atendiendo a su barbacana, organo defensivo al parecer inaugurado en Al-Ándalus en las dominaciones almorávide-almohade, Chera sería de los inicios del siglo XII. No faltan fortalezas ceñidas por barbacana de planta semejante a los muros torreados principales: tramo de muralla almohade de Sevilla entre las puertas de la Macarena y la de Córdoba, alcazaba de Antequera y castillo del Alcázar de Marchena, en Carmona.

Más problemático es ver un ribat en Chera atendiendo a su planimetría, pues en realidad el ribat en Al-Ándalus no llegó a alcanzar

${ }^{30} \mathrm{Paz}, \mathrm{R}$., "Visitas a encomiendas de la Provincia de Castilla en el siglo XV", Miscelánea de estudios dedicados al profesor Antonio Marín Ocete, Granada, 1974, pp. 184-185. 
una forma definida, dándose ribat en castillos -castillo de Fuengirola-, albacares, mezquitas y torres atalayas e incluso en ciudades o medinas, como es el caso de Mahdiyya (Túnez). Es probable que en Sharq alÁndalus, al igual que en otras comarcas, la voz ribat alternaría con la de al-munastir, como se ve en el Almonastil de Alicante o en Castellón, por la Sierra de Espadán, Vall de Almonacid, ambos hábitats citados en el siglo XIII. Por alli mismo existe el topónimo del "Pico de la Ràpita". Julián Ribera y Tarrag $^{31}$ nos informa que habra en Denia hacia el siglo $X$, en las faldas del Mongó y junto al mar, una especie de monasterio o fortaleza a donde se retiro para hacer vida de ribat Abulmotárrif, discípulo del célebre alfaquí granadino Abenabizamanín, el cual alternaba sus rezos y vida contemplativa con la tarea de plantar árboles en torno al monasterio. La semejanza en planta del castillo de Chera y el gaditano de San Romualdo, supuesto ribat, puede alumbrar algo sobre la función de la fortaleza valenciana. La fortaleza de Chera, prácticamente única en Al-Ándalus por su planimetría, es un ejemplo singular en la arquitectura hispanomusulmana.

\section{4- A MODO DE SÍNTESIS DE LA ARQUITECTURA MILITAR DE $S H A R Q A L-A N D A L U S$}

No es mi proposito hacer aquí una exposición amplia, acompañada de bibliografía exhaustiva, de la castellología de Sharq al-Ándalus, que desde hace años viene siendo objeto de estudio por investigadores locales, nacionales y extranjeros ${ }^{32}$. Estos últimos años he viajado por las provincias de Valencia, Castellón, Alicante y Murcia, con la

31 "Un monasterio musulmán en Denia", Disertaciones y opúsculos, II, 1928, pp. 203-205.

${ }^{32}$ Vallvé Bermejo, J., "La división territorial de la España musulmana (II). La cora de Tudmir (Murcia)", Al-Andalus, XXXVI, 1972; Azuar, R., Castellología medieval alicantina, Alicante, 1981; Navarro Palazón, J., "De la Murcia musulmana a la Murcia cristiana (s. VIII-XIII). Aspectos arqueológicos", Historia de la Región Murciana, III, 1981; Bazzana, Cressier, Guichard, Les châteaux ruraux d'Al-Andalus. Histoire et archéologie des husun du Sud-Est de l'Espagne, Madrid, 1988; Epalza, M., "Funciones ganaderas de los albacares en las fortalezas musulmanas", Sharq al-Andalus, I, 1984; Llobregat, E.A., "De la ciudad visigótica a la ciudad islámica", La ciudad islámica, Zaragoza, 1991. 
intención de examinar de cerca multitud de fortalezas de esta zona oriental de la Península, examen que tiene por finalidad completar mi segundo tomo de Tratado de arquitectura hispanomusulmana. Ciudades $y$ fortalezas ${ }^{33}$. De manera que ahora me propongo dar sólo una rápida visión de esa experiencia, conjugándola en lo posible con lo que he ido cosechando en el resto de la Península Ibérica.

No es fácil hacer síntesis de la tierra dominada por los árabes que nos ocupa. Lo árabe por donde pasa todo lo uniforma. Cada dinastía impone una uniformidad; la suma de ellas es Al-Ándalus. En lo militar, la arquitectura árabe resultó más agresiva que la occidental, con órganos defensivos infinitamente superiores, copiados de inmediado por los cristianos. La arquitectura militar de Sharq al-Ándalus de los siglos XIXII, paradojicamente, en muchos aspectos se asemeja a la del lado opuesto de la Península, es decir, Gharb al-Ándalus, en tierras portuguesas $^{34}$ y de Extremadura, siendo ello claro exponente del empuje militar desplegado intencionadamente y con igual intensidad en los dos extremos por los nuevos invasores africanos. Sin embargo, hay un organo defensivo-ofensivo fundamental, la torre albarrana, prácticamente inédita en Levante, exceptuada la del castillo valenciano de Corbera, estudiada por Bazzana ${ }^{35}$. Extremadura y Portugal, con los almohades, son ricas en esas torres exteriores. Tampoco se prodiga la puerta con ingreso en recodo: alcazaba de Denia, las abarbacanadas de Santa Eulalia y de los Vidrieros de Murcia y la de Chera, castillo de Alcalá de Mula, aparte de las cristianas de la villa del llano de Penáguila y Perpunxent. No se citan corachas -qawraya-, superficiales o subterráneas, si bien en Morella existe el topónimo "corachar", y aquella torre albarrana de Corbera bien pudo ejercer la función de coracha con una fuente de agua próxima. En Sharq Al-Ándalus, la agreste y montuosa topografía, que tanto distanciaba la fortaleza

33 Pavón Maldonado, B., Tratado de arquitectura hispanomusulmana, t. I, Agua, Madrid, 1990.

${ }^{34}$ Pavón Maldonado, B., Ciudades y fortalezas lusomusulmanas.

35 Bazzana, A., "Éléments d'archéologie musulmane dans al-Andalus: caractères spécifiques de l'architecture militaire arabe de la région valencienne", Al-Qantara, I, 1980. 
encumbrada de la corriente fluvial, cuando existía -pongo por caso el castillo de Ricote, al pie del Segura-, anulaba toda posibilidad de toma de agua directa, de ahr la multiplicidad de aljibes de la lluvia en el castillo y sus albacares. Quizá a ese carácter agreste se deba la prácticamente nula presencia de torres albarranas; éstas, fundamentalmente, se reservaban para el llano o terreno poco accidentado.

Realmente, quien presuma de haber subido a los castillos más elevados de la Península reconocerá que ninguno ofrece tanta dificultad en su ascensión como los alicantinos y los murcianos, el de Ricote, Penáguila, Alcalá, Cocentaina, Almiserá, Orihuela, Mariola, Cox, Callosa. El hábitat árabe en Sharq al-Ándalus residŕa, temporalmente y en tiempos de peligro, en montes y sierras excesivamente encumbradas, lo que condicionó su arquitectura militar, sintetizada en una gran torre atalaya autosuficiente, con recinto abarbacanado o albacar y el consabido aljibe, esto de una parte; de otra igualmente excesiva austeridad sin más concesión reconocida de orden decorativo que la torre monumental de Villena y algo en la de Biar, la de Aledo y su réplica en la Torre Alfonsina de Lorca. Estas torres festivas por el interior -sobre todo en las bóvedas-, en contraste con los muros completamente lisos del exterior, se alinean con la torre almohade de la calle de Porvera, en la cerca de Jerez de la Frontera, Torre de la Vela y la del Homenaje de la alcazaba de la Alhambra o de la de la Cárcel, de aspecto almohade-mudéjar, del castillo de la Mota, de Alcalá la Real (Jaén).

Todo con los almorávides y almohades era tapial hormigonado tan consistente como nuestro actual cemento; y se revestran los paramentos de falso aparejo de sillares pintados de rojo, amarillo ocre, blanco o rojo, de ahí las torres del Oro, las Blancas o Albaydas o de la Plata, las Bermejas, que han quedado en la toponimia. Las saeteras, por lo general, siguiendo la moda almohade, estaban debajo de los merlones prismáticos -Alcalá de Gallinera y castillo de Sagunto-, con remates a veces apiramidados. Se rehuía la torre redonda, menos las poligonales -al pie del Segura en Orihuela y torre de la muralla urbana de Alpont-. Probablemente las torres redondas de Alcira fueran árabes, como una de la cerca de Játiva, precedidas de las romanas-bizantinas de Cartagena. Falta en Levante la torre de Faro, es decir, almanara propiamente dicha -no así el topónimo-, baluarte de dos pisos, el superior, de menor 
planta, a modo de pabellón del almuédano, para cobijo del centinela $\mathbf{u}$ hogar del fuego o fogata, como se ve la torre de Espantaperros de la Alcazaba de Badajoz, en la sevillana torre del Oro o en una torre de la alcazaba de Guadix. Pienso que este tipo de almanaras existian en Levante, todas relacionadas y en parejas gemelas de la gran almanara de la alcazaba de Susa (Túnez), del siglo IX, estudiada por Lézine, que tiene la puerta a dos o tres metros sobre el nivel del suelo, como en las talayas hispanomusulmanas, pongo por caso la del castillo de Mariola. Esa torre tunecina tiene pronunciado talud y en el interior había una mezquitilla. La escalera gira en torno a machón central con habitaciones superpuestas; es decir, la estampa viva de un faro, del que derivan asimismo la Giralda y la Torre del Oro. En el paisaje arquitectónico castrense de Sharq al-Ándalus, aún poco conocido y de talante tan austero, llaman la atención plantas como las del castillo de Monteagudo y el "Castillejo" de la Vega de Murcia y la de la valenciana fortaleza de Chera.

Esta uniformidad impuesta por los almorávides y, sobre todo, por los almohades en tierras levantinas a través de los tapiales hormigonados, bien patentes en las torres del Valle del Vinalopó y las del paso de Gallinera, nos da una imagen castrense peculiar que lo es también de todo Al-Ándalus. Me refiero al sistema de torres y castillos atalayas que jalonan los valles y caminos o calzadas, éstas a veces pisando las preislámicas, como ha reconocido María Jesús Rubiera en su libro sobre Villena. Yo he reunido en esquema gráfico con escala varias de esas torres vigía, con o sin albacar o barbacana, que a veces generan una fortaleza o castillo, que incluye aljibe, generalmente dispuesto al pie y por fuera del baluarte, excepto la primitiva torre árabe del castillo o fortaleza residencial de Fornas, con cisterna dentro y en medio de la primera planta. En ese esquema destacan las dimensiones de las torres de Villena, Biar y Mola, también la de Jijona, quizá significando la mayor importancia militar de éstas, frente a las restantes de tamaño ordinario.

María Jesús Rubiera, apoyándose en Jaime Oliver, dice que este sistema de atalayas es el mismo que el de la Marca Media, y podemos añadir que el de todo Al-Ándalus. Es un sistema árabe secular, que se adentra en la época omeya, al menos en las tierras comprendidas entre el río Tajo y el Duero, con su prolongación hasta el Ebro. En esa 
extensa zona se ven torres colosales, verdaderas calahorras a la vez que atalayas -Noviercas, Mezquetillas, Soliedra, Bujarrabal, etc.--, de época califal, y con fábricas de aparejo de soga y tizón semejantes a las de la gran torre de Alpont (Valencia), emplazada en la transición de las tierras de Valencia y de Cuenca. Esta torre inicialmente era torre atalaya del siglo X. Pero, ¿qué se sabe de este tipo de construcción con aparejo omeya, en las provincias de Murcia, Castellon y Alicante? María Jesús Rubiera dice que las fortalezas árabes levantinas de los siglos VIII, IX y $\mathrm{X}$ serían suplantadas por las almorávides y las almohades, que son las que han llegado a nuestros días. Es elocuente al respecto este texto del Muqtabis de Ibn Hayyān, evocado por la doctora Rubiera: "Alicante está sobre el mar con el conjunto de castillos a ella unidos, y las alcazabas que están a su alrededor". El texto, escrito en el siglo $\mathrm{X}$, sin duda hace alusión a fortalezas omeyas, pero ¿qué tipo de fábrica tenían? ¿eran de tapial hormigonado como el castillo califal de Baños de la Encina o los muros de la fortaleza y villa de Segura de la Sierra? Pienso que de haber existido en Sharq al-Ándalus fortalezas de piedra de la etapa omeya, cual es el caso de Alpont, hubieran sido respetadas y hubieran resistido hasta nuestros días. Nunca se sabrá si la fortaleza de Orihuela, mandada derribar por 'Abd al-Raḥmãn III, según Ibn Hayyān, era de sillares. Ello nos lleva a admitir que en esta zona de Al-Ândalus de siempre las construcciones militares fueron de tapial hormigonado y que la acción de los emires y califas de Córdoba no alcanzó una influencia decisiva o importante en ella, al punto de no haberse reflejado en una arquitectura más oficial de piedra.

Las fábricas y sistemas constructivos árabes levantinos son una informe amalgama de tapiales, tapiales hormigonados, mamposterias de hiladas regularizadas y muros mixtos de mampostería y tapial. Nada de piedra o sillares bien escuadrados. Ésta es la herencia islámica que nos ha llegado, lo que no está reñido con la presencia de restos cerámicos, viscochados o vidriados, de época omeya o del siglo XI, que se pueden rescatar al pie de esos muros de tapial: Murcia, Orihuela, Denia, Monteagudo, castillo de Mariola, Cocentaina e incluso el alto de Almiserá, por poner algunos ejemplos. La textura del tapial hormigonado, de otra parte, merece ser atendida en determinados casos. La torre de Villena es, con mucho, de una solidez proverbial: un hormigón casi indestructible, tanto como el del castillo califal de Băños de la Encina, 
restos de muro árabe conservado en el castillo cristiano de Segura de la Sierra, torre de Setenil (Málaga) y torre de Aledo (Murcia). Ese mismo tipo de hormigón se deja ver en Mariola e incluso en Penáguila. Lo difícil es distinguir dos o más tipos de tapial en una misma fortaleza, como exponentes de épocas diferentes, según se advierte, por ejemplo, en Guadix (Granada), con alcazaba de tapias más deleznables que los muros de la medina (s. X-XI). Éste es el caso de Villena: los muros de la torre, con espesor de 3,80 metros, son infinitamente más consistentes que la muralla del albacar; lo mismo ocurre en Penella, cuya torre atalaya, de época tardía, se aparta de tapiales más consistentes de la muralla contigua. Y otro caso es el de la torre principal de Fornas, sin duda atalaya islámica muy antigua. Alcalá de Gallinera es un amasijo de fábricas de todo tipo, sobresaliendo muros mixtos de mampostería y tapial encima, como en el castillo de Orihuela y el de Callosa. Y en Cocentaina la actual atalaya del castillo cristiano del cerro suplantó a otra árabe de la que tan sólo se ha conservado un aljibe, actualmente ruinoso. La puerta del albacar de Planes, de muros de tapial, como se ha visto, nos lleva a las postrimerías del siglo XI o principios del XII. $Y$ si nos referimos a torres atalayas del llano o el valle -la de Macanes o Manzanas, sin duda del árabe al-manzar, con el significado de torre mirador o vigía, Agres, las de la Almudaina y Carricola- son de tapial con mechinales, siempre huecas por dentro; es decir, tenían plantas de pisos improvisados de madera, según norma generalizada desde el siglo $X$ : castillo califal de Baños de la Encina y atalayas de la provincia de Jaén. De entre esas fábricas destaca a veces la mampostería hormigonada, es decir, tapias de piedra con mechinales, cual es el caso del castillo de Olocau (Valencia) ${ }^{36}$, que se deja ver en otras fortalezas alicantinas de segundo orden.

Atendiendo a su especial clase de tapial hormigonado, la gran torre de Villena, con planta cuadrada de 15 metros de lado, pudo ser fortaleza prealmohade y quizá anterior a los almorávides, como la murciana de Aledo, de hormigón durísimo, zócalo con zarpa al exterior y bovedas hechas con ese mismo material, todo muy semejante a la de

36 Pavón Maldonado, B., "Contribución al estudio del arabismo de los castillos de la Península Ibérica (Región Levantina). El castillo de Olocau de Valencia", Al-Andalus, LXLII, 1977, pp. 207-225. 
Villena. La de Aledo -planta cuadrada de 12,85 metros de lado- consta que fue asediada por los almorávides en la última década del siglo XI. Conviene tener presente que las torres grandes califales por encima de los 10 metros de lado son las del Trobador de la Aljafería de Zaragoza $-16,50$ por 11,50 -, Novierca (Soria) $-12,35$ por $8,87-$, Mezquitillas (Soria) $-14,43$ por 10,05-, atalaya de Toya (Jaén) $-11,30$ por 10,80-. La razón de estas torres de gran envergadura es que eran baluartes autosuficientes capaces en casos extremos de retener una guarnición entera. Dentro de la dominación islámica, erigidas entre los siglos XII y XIII, las torres más monumentales son la Calahorra de Gibraltar -20 por 17 metros-, la de ángulo de Antequera $-17,70$ por 16,75 metros- y la de la Vela de la alcazaba de la Alhambra -16 metros de lado-. Todas ellas responderfan por el nombre árabe de burý o el de la qal'a hurra. Las torres atalayas ordinarias, cuadradas o rectangulares, no rebasaban los 8 metros de lado: Almudaina -6,70-, Chera -7,00-, Benifallim -7,99 por 7-o Carricola.

Según se ha visto, la fortaleza reina de Levante era la torre atalaya, con entrada en alto y rodeada de cerca muy ceñida, tipo bien definido en Carricola, Sot de Chera, Chetvas, torre del llano de Agres y Benifallim. No faltaba el simple albacar o recinto murado con torres, con o sin torre maestra dentro: Planes, Carbonera, Gallinera, Agres. A veces la torre atalaya es sustituida por un castillete provisto de amplio albacar con su aljibe: el murciano castillo de la Luz, Monteagudo, Orihuela, Cocentaina, Alicante, Olocau, Onda, Pliego. Todas estas fortalezas respondían por el nombre de hiṣn, y cuando lo permitían las condiciones del terreno en alianza con una posición estratégica privilegiada, surgía la qal'a, como Alcalá de Chivert, Alcalá de Gallinera y Alcalá de Mula. Surgieron aquellas dos, al igual que la mayoría de Al-Ándalus, como fortalezas a la vez que hábitats estables, primero dentro de los albacares y después en extramuros. Fueron verdaderas villas o madinas, y como tales se mantuvieron por algún tiempo en la dominación cristiana. Cuantos Alcalá han subsistido nos llegan como grandes y florecientes poblaciones con su núcleo preurbano, cerca o distante de la fortaleza árabe inicial o qal' $a$, excepto Alcalá de Mula y Alcalá de Gallinera, abandonadas quizá entre los siglos XIV y XV. Respecto al albacar o a los albacares, término que no figura en las crónicas árabes -en la dominación islámica serían conocidos por al- 
'askar o al-hizäm-, los de Sharq al-Ándalus generalmente tienen muros menos gruesos que los de los castillos o torres a los que protegen, de 0,90 a 1,20 metros, norma no aplicable a otras regiones de Al-Ándalus.

Me he referido antes a los aljibes, una vez en el interior de las torres, pero los más emplazados al pie del baluarte, clisé éste muy generalizado en Al-Ándalus; y si la fortaleza tenía uno o varios albacares, una cisterna por cada uno de ellos. Se comprueba que las fortalezas islámicas con mayor número de aljibes son las de Játiva, Sagunto, Alcalá de Mula y Alpont. Lógicamente eran usuales los estanques o albercas camineras, ubicadas en la falda de los montes coronados por castillos. María Jesús Rubiera habla por el camino de Villena de el Zaricejo, del arabismo Zafarache -al-sahr $r \bar{l}$-, tratado por la doctora Garulo ${ }^{37}$. Pues bien, al pie del cerro encumbrado del castillo de Callosa se ve una de esas albercas o estanques árabes, que tomaba el agua de una vaguada rocosa que descendía desde la cumbre de la fortaleza. Tiene planta rectangular $-12,25$ por $3,82-\mathrm{y}$ es de fortísimo hormigón de color rojo o almagra en los paramentos del interior, con zarpas y una dependencia pequeña contigua. Se ve perfectamente un rebaje en una de las paredes para entrada del agua desde el cauce rocoso del monte.

Como advertencia final y orientación recordamos qué castillos, madinas o fortalezas anteriores al siglo XII se citan en las crónicas árabes, sin comprometernos aquí a mencionar esas fuentes: Valencia, Alcira, Játiva, Sagunto, Cullera, Almenara, Olocau, Lorca, Murcia, Chinchilla, Ricote, Mula, Orihuela, Molina de Segura, Denia, Sujur, Aspe, Biar, Elda, Alicante, Callosa, Denia, Cocentaina, Gallinera. A partir del siglo XIII prácticamente todos los castillos medievales alicantinos están citados en la obra Alicante y su territorio en la época de Jaime 1 de Aragón ${ }^{38}$. El problema del binomio hiṣn - madina que se aplica en las fuentes a algunos de esos hábitats -pongo por caso

${ }^{37}$ Garulo, T., "Toponimia hispano-árabe. Al-sahrīŷ", Al-Qantara, I, 1980, pp. 27-41; y Pavón Maldonado, B. "Notas sobre arte y arqueología hispanomusulmana en Andalucía", Andalucía Islámica. Textos y Estudios, II-III, 1981-1982, pp. 209-210.

${ }^{38}$ Martínez Ortiz, J., Alicante y su territorio en la época de Jaime I de Aragón, Alicante, 1993. 
Orihuela, a la que se llega a conocer también como alcazaba e incluso qal'a - no parece tal problema puesto que los árabes instalan esa dualidad en multitud de villas o ciudades de todo el Al-Ándalus. Es decir, el hábitat aludido unas veces es llamado castillo por la fortaleza que presidía la población, y otras madina en su sentido más amplio implicando ello la existencia de murallas, mezquita o mezquitas y mercados. Sobre si algunos castillos levantinos tenían mezquitas, caso poco habitual en Al-Ándalus, Madoz escribe: "el castillo de Tárbena con mezquita".

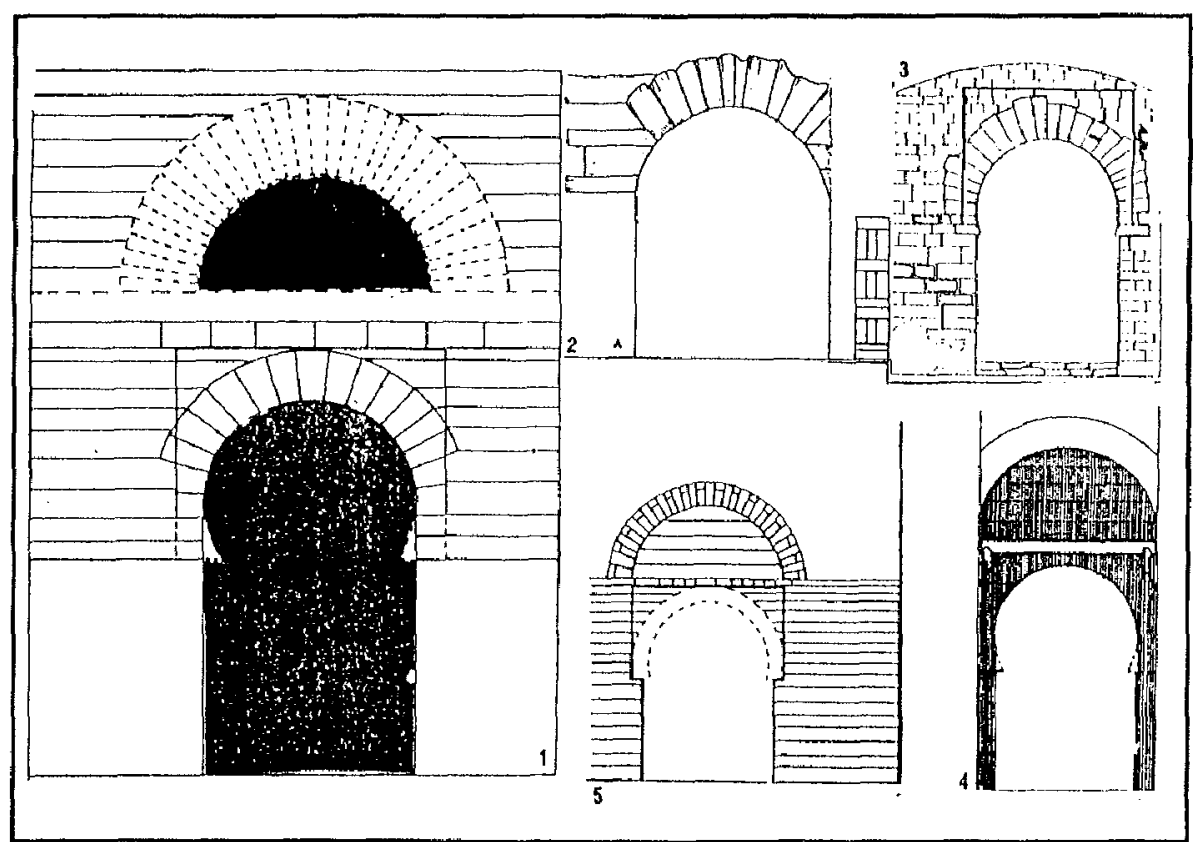

Fig. 1 1. Puerta del Castillo, Castro del Río (Córdoba); 2. Puerta de Alpont (Valencia); 3. Puerta Torre del Mig, Denia (Azuar); 4. arco visto por el interior; 5. arco exterior. 


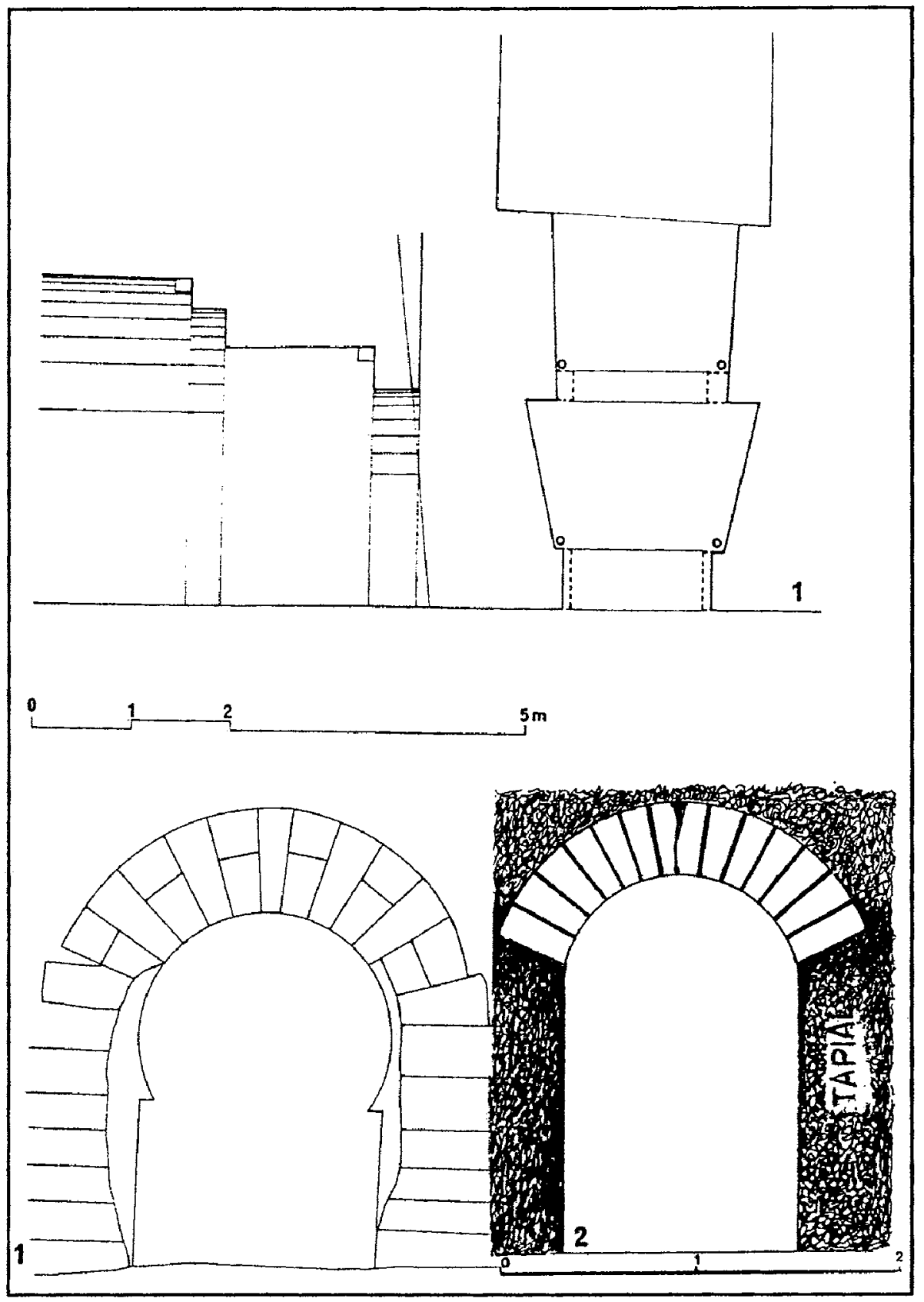

Fig. 2 1. Puerta del Baluarte, Alcazaba de Denia; 2. Puerta de Ibiza. 


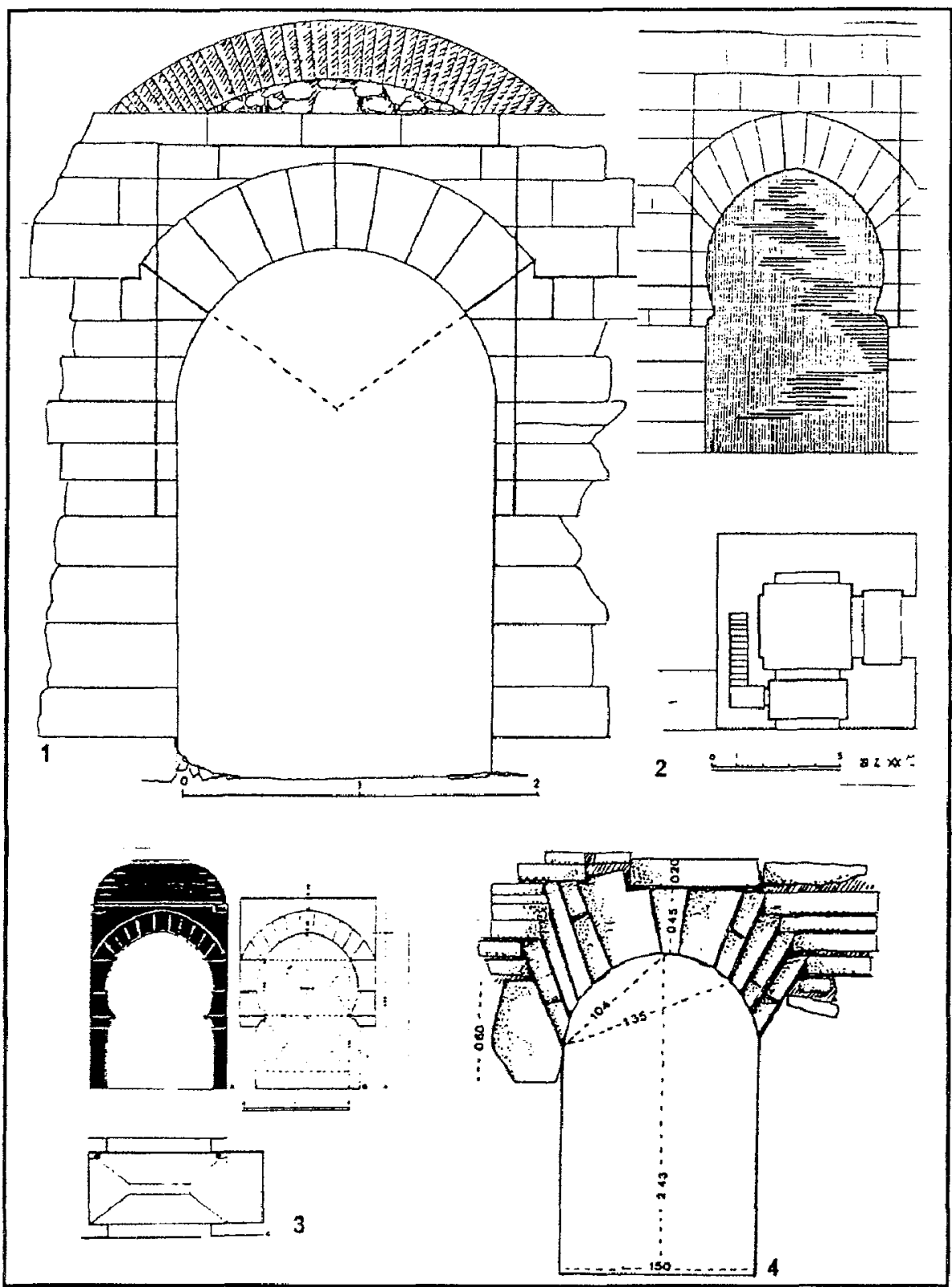

Fig. 3 1. Puerta del Castillo de Alcaudete; 2. Puerta de la Torre de Belén (Córdoba); 3. Puerta del Castillo, Alcalá la Real (Jaén); 4. Puerta del Castillo de Planes (Alicante). 


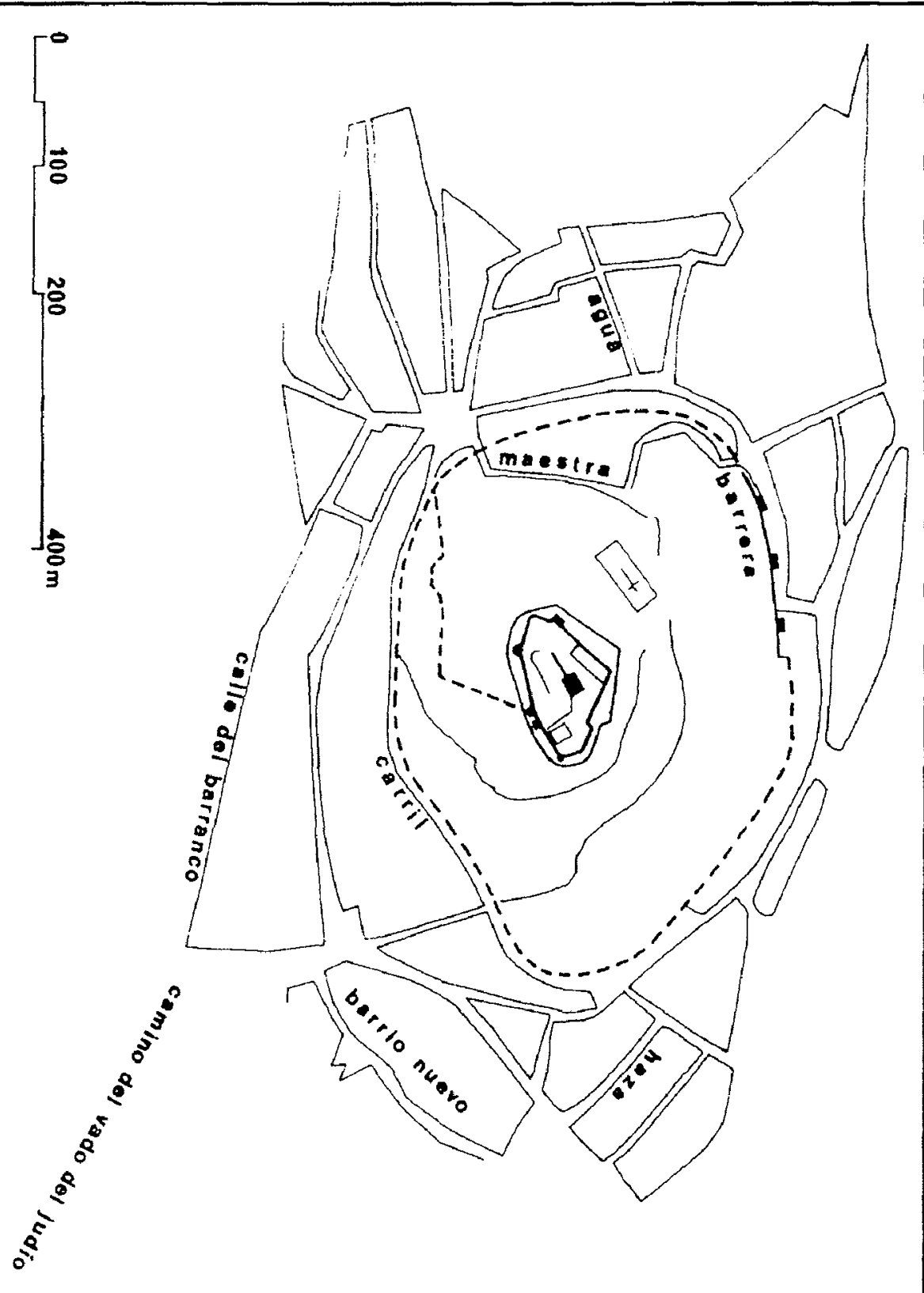

Fig. 4 Castillo y recinto antiguo. Alcaudete (Jaén). 


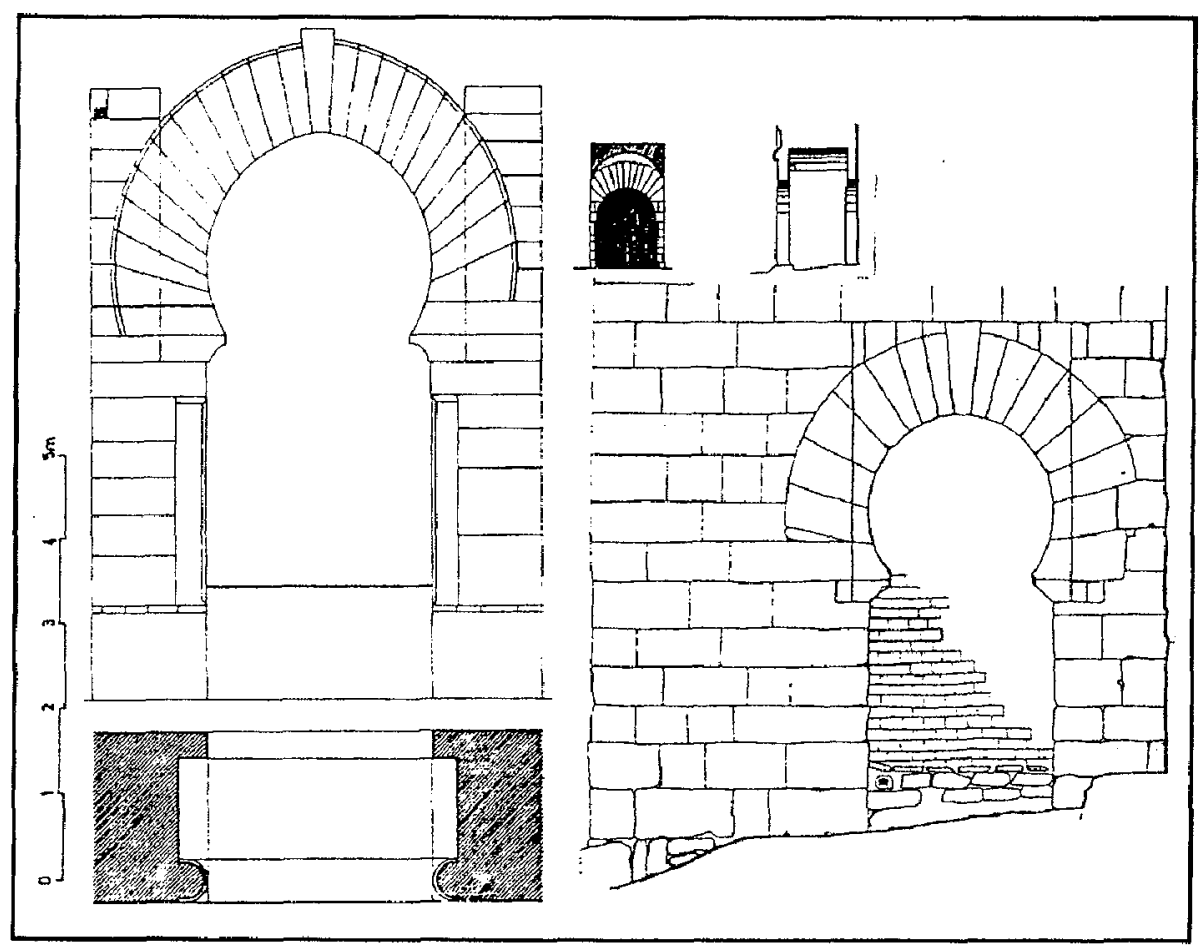

Fig. 5 A. Puerta de la Pastora, Medina Sidonia (Cádiz); B. Puerta del castillo califal de Tarifa. C. Puerta del Buey, Niebla; fachada exterior. 

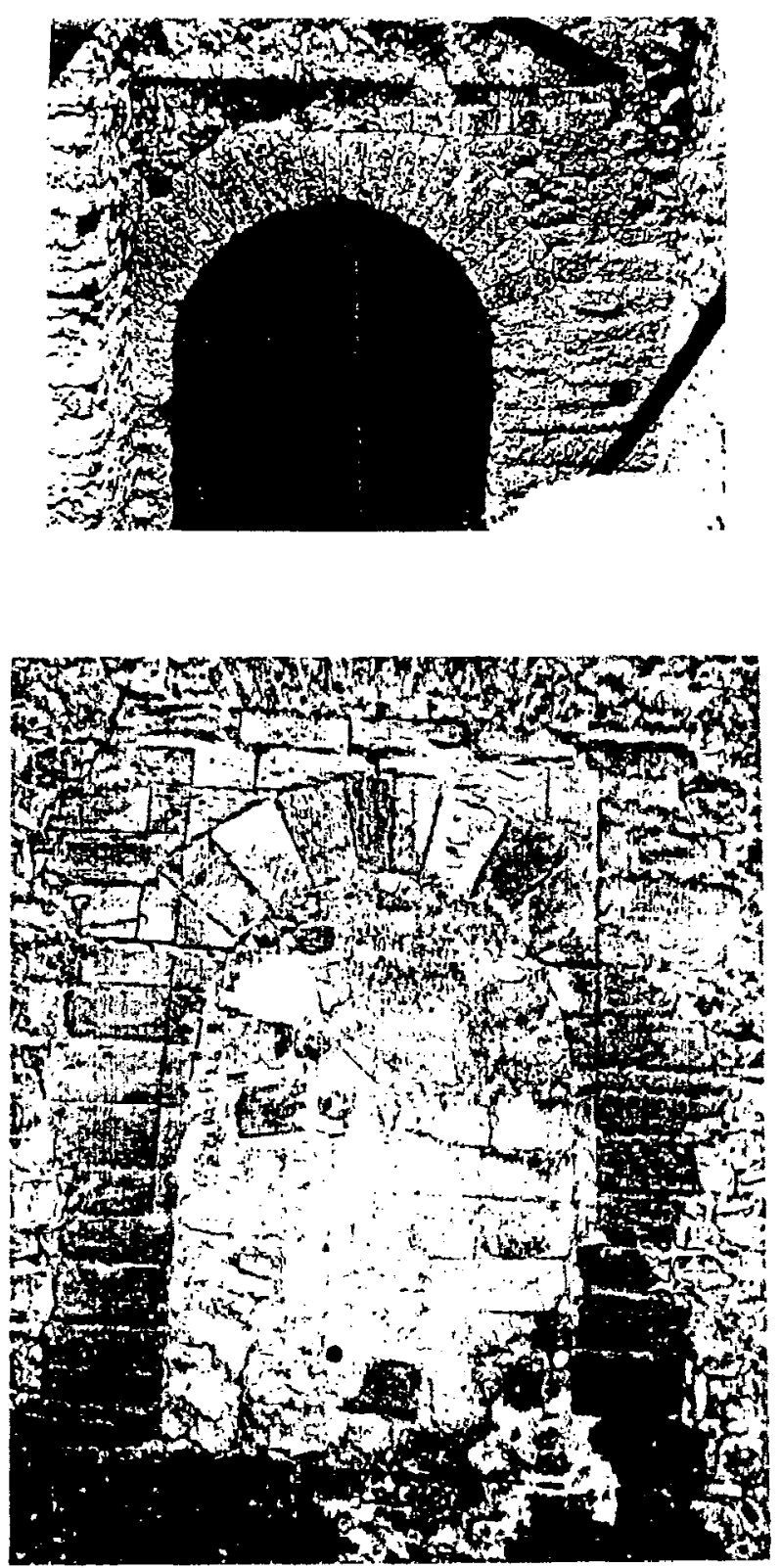

Fig. 6 A) Puerta de la Torre del Mig, Denia: arco interior; B) Puerta árabe del castillo de Alcaudete (Jaén). 


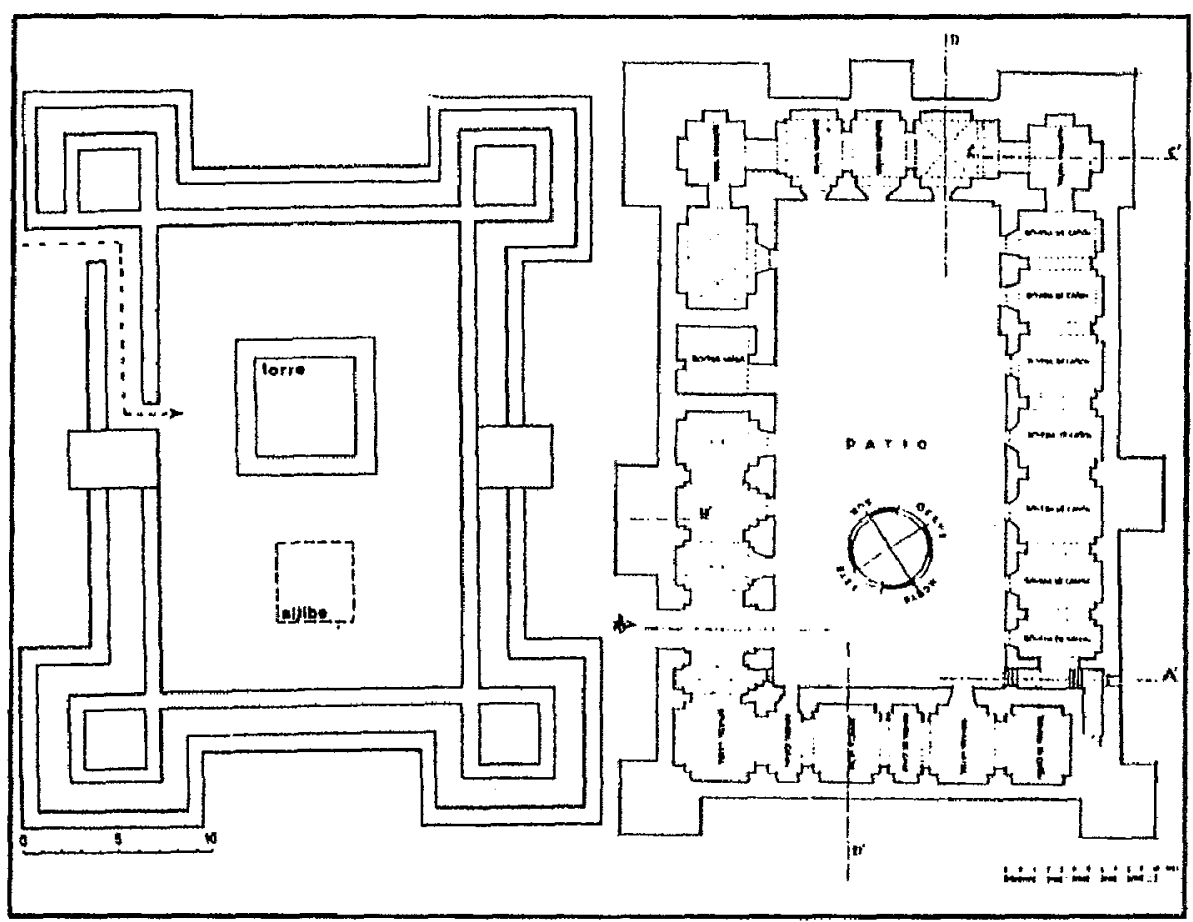

Fig. 7 A) Castillo de Chera (Valencia); B) Castillo de San Romualdo,-Isla de San Fernando, Cádiz (Según Torres Balbás). 


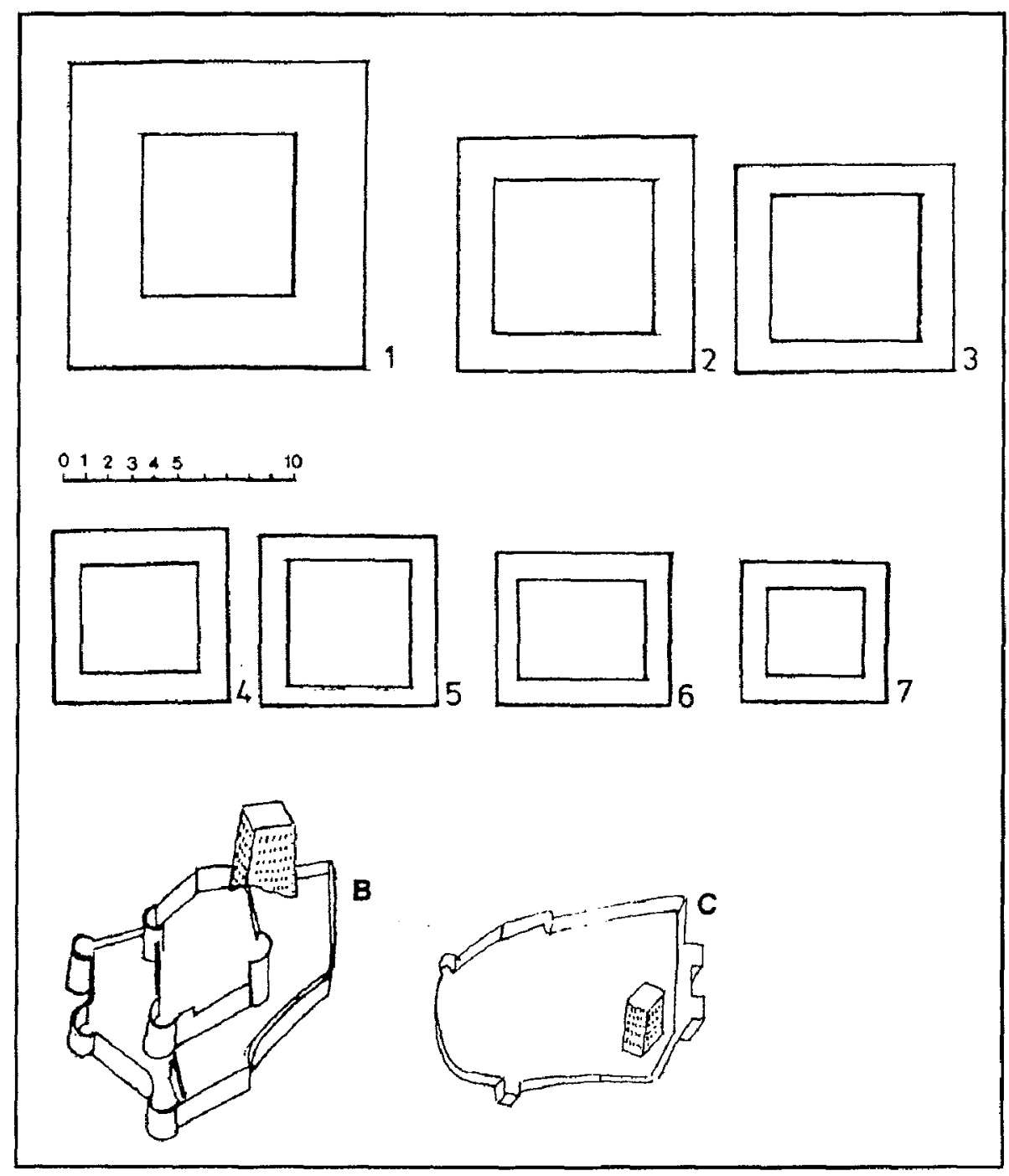

Fig. 8 Torres de castillos árabes de la provincia de Alicante: 1. Villena; 2. Novelda; 3. Petrel; 4. Biar; 5. Bañeres; 6. Jijona; 7. Sax. B) Castillo de Biar; C) Castillo de Novelda. 